\title{
PENGEMBANGAN KAPASITAS SDM DALAM DUNIA PENDIDIKAN PADA SMPN 83 JAKARTA
}

\author{
Karolina, Endang Sugiarti, Enok Nurhasanah, Endang Puji Astutik, Prihadi \\ Dwianggoro \\ Program Studi Manajemen \\ Universitas Pamulang \\ dosen02476@unpam.ac.id
}

\begin{abstract}
The purpose of devotion to this community to provide training to the teachers in making questions about the Higher Order thinking Skills/HOTS) at SMPN 83 Jakarta. The methods used are several stages of preparation, which include preliminary surveys, commissioning and determination of the location and objectives. After the survey it is determined the location of implementation and target participants activities. The next stage is the implementation of community devotion. This stage will be given an explanation on the development of human resources, namely teachers in education. The session focuses on teachers ' skills in making HOTS and the latter a training stage, with several methods including lectures, questions and answers and simulations. The results of the public devotion is an increase of scholarly knowledge for teachers who performed on SMPN 83 Jakarta located at Jl. Empang Bahagia Raya Jelambar, Kec. Grogol Petamburan, Jakarta Barat Prov. D.K.I. Jakarta, with 21 teachers and teachers, so that they will be able to develop good human resources in education, teachers can apply the Higher Order Thinking Skills (HOTS) to encourage learners to think broadly and in depth about the subject matter. The knowledge gained on community devotion this time is expected to improve student competence through coaching teachers in planning, implementing, and evaluating learning oriented towards high Order thinking skills (HOTS).
\end{abstract}

Keywords: HR Capacity, Education World

\begin{abstract}
Abstrak
Tujuan pengabdian kepada masyarakat ini untuk memberikan pelatihan kepada para guru dalam membuat soal Higher Order thinking Skills/HOTS) di SMPN 83 Jakarta. Metode yang digunakan ada beberapa tahap diantaranya tahap persiapan, yang meliputi survey awal, pemantapan dan penentuan lokasi dan sasaran. Setelah survey maka ditentukan lokasi
\end{abstract}


pelaksanaan dan sasaran peserta kegiatan. Tahap berikutnya yaitu tahap pelaksanaan Pengabdian Kepada Masyarakat. Tahap ini akan diberikan penjelasan mengenai Pengembangan Kapasitas SDM yaitu para guru dalam Dunia Pendidikan. Sesi ini menitikberatkan pada ketrampilan para guru dalam membuat soal HOTS Dan yang terakhir merupakan tahap Pelatihan, dengan beberapa metode diantaranya ceramah, tanya jawab dan simulasi. Hasil pengabdian masyarakat yang diperoleh adalah bertambahnya keilmuan bagi para para guru - guru yang dilakukan pada SMPN 83 Jakarta yang berlokasi di Jl. Empang Bahagia Raya Jelambar, Kec. Grogol Petamburan, Kota Jakarta Barat Prov. D.K.I. Jakarta, dengan guru - guru yang berjumlah 21 perserta, agar mereka mampu mengembangkan kapasitas SDM yang baik dalam dunia Pendidikan maka, para guru bisa menerapkan ketrampilan berpikir tingkat (Higher Order Thinking Skills/HOTS) untuk mendorong peserta didik untuk berpikir secara luas dan mendalam tentang materi pelajaran. Ilmu yang diperoleh pada pengabdian masyarakat kali ini diharapkan mampu meningkatkan kompetensi siswa melalui pembinaan guru dalam merencanakan, melaksanakan, sampai dengan mengevaluasi pembelajaran yang berorientasi pada Keterampilan Berpikir Tingkat Tinggi (Higher Order thinking Skills/HOTS).

Kata Kunci : Kapasitas SDM, Dunia Pendidikan.

\section{A. PENDAHULUAN}

Mutu pendidikan menjadi masalah yang sejak dulu senantiasa diupayakan peningkatannya oleh pemerintah. Pengendalian mutu pendidikan pada dasarnya adalah pengendalian mutu SDM (sumber daya manusia) yang berada dalam sistem tersebut. Untuk mengetahui pengendalian ini dibutuhkan informasi mengenai keadaan peserta didik, apakah ada perubahan, apakah guru berfungsi, apakah sekolah mendukung terlaksananya programprogram pendidikan sehingga hasilnya bisa dicapai secara optimal. Salah satu cara yang dilakukan untuk dapat mengendalikan mutu dalam pendidikan adalah dengan melakukan assessment (penilaian).

Penilaian perlu dilakukan untuk mengukur sejauh mana kompetensi yang telah dicapai peserta didik dalam proses pembelajaran, dimana pada kurikulum 2013, penilaian diatur dalam Permendikbud Nomor 66 Tahun 2013 (Kemdikbud, 2013: 6) tentang Standar Penilaian Pendidikan meliputi penilaian otentik, penilaian diri, penilaian berbasis portofolio, ulangan harian, ulangan tengah semester, ulangan akhir, ujian tingkat kompetensi, ujian mutu tingkat kompetensi, ujian nasional dan ujian sekolah/madrasah. Penilaian ini merupakan penilaian hasil belajar yang dilakukan oleh pendidik, satuan pendidikan dan pemerintah. Penilaian hasil belajar diharapkan dapat membantu peserta didik untuk meningkatkan kemampuan berpikir tingkat tinggi (Higher Order Thinking Skills/HOTS), karena berpikir tingkat tinggi dapat mendorong peserta didik untuk berpikir secara luas dan mendalam tentang materi pelajaran. 
Keterampilan berpikir tingkat tinggi atau HOTS merupakan solusi untuk mengejar ketertinggalan. Untuk mengejar ketertinggalan tersebut seseorang harus survive, dimana seseorang harus mampu memiliki kemampuan berpikir tingkat tinggi untuk memecahkan permasalahan yang dihadapi. Seseorang yang menggunakan keterampilan berpikir akan lebih mudah dalam menyelesaikan suatu pekerjaan dibandingkan dengan seseorang yang kurang menggunakan keterampilan berpikir keterampilan berpikir tersebut dapat dimulai dari berpikir tingkat rendah hingga berpikir tingkat tinggi.

Peserta didik perlu dilatih dalam hal keterampilan berpikirnya dengan cara memberikan peserta didik tersebut soal yang memiliki tipe HOTS yang dapat digunakan untuk memperbaiki keterampilan berpikir dari peserta didik. Soal tersebut dibuat dengan menerapkan kompetensi dasar yang dapat digunakan untuk mengukur keterampilan berpikir tingkat tinggi dari peserta didik.

Dalam membuat penilaian yang berkarakteristik HOTS memerlukan keahlian seorang guru dalam membuat soal yang berbobot. Akan tetapi pendapat dari Nuh (dalam Kartini, 2011: 8) menyatakan bahwa guru yang sudah mengikuti sertifikasi belum berhasil menunjukkan kompetensinya dari sisi pedagogi, profesional, sosial dan kepribadian. Keaktifan guru terlihat hanya menjelang sertifikasi sedangkan setelahnya, kualitasnya mengalami penurunan. Penilaian kualitas guru di negara maju sejak 20 tahun terakhir telah menjadikan Kerangka Kualifikasi Nasional Indonesia (KKNI) sebagai standar. Oleh karena itu, kami Dosen Universitas Pamulang dan Yayasan Sasmita Jaya beserta karyawan dan mahasiswa telah mengadakan Pengabdian Kepada Masyarakat (PKM) bekerjasama dengan Sekolah SMPN 83 Jakarta memberikan pemahaman dan pelatihan tentang "Pengembangan Kapasitas SDM Dalam Dunia Pendidikan”.

\section{B. METODE PELAKSANAAN KEGIATAN}

Metode kegiatan yang digunakan adalah bekerjasama dengan Kepala Sekolah SMPN 83 Jakarta dan mencari pemasalahan yang ada di tempat tersebut sehingga dapat memberikan solusi yang tepat dalam meningkatkan ketrampilan para guru dalam pembuatan soal HOTS. Setelah di analisis maka kami memberikan pengetahuan, pengembangan dan pelatihan dalam pembuatan soal HOTS di SMPN 83 Jakarta. Para guru diharapkan mampu dalam membuat soal HOTS agar peserta didik memiliki kemampuan dalam berpikir tinggi dalam memecahkan masalah. Bagi pihak sekolah diharapkan agar selalu melakukan penilaian dalam hasil belajar agar membantu peserta didik untuk meningkatan keterampilan berpikir tingkat tinggi karena berpikir tingkat tinggi dapat mendorong peserta didik untuk berpikir secara luas dan mendalam tentang materi pelajaran.

Metode pelaksanaan kegiatan akan disajikan secara lengkap melalui penjelasan dibawah ini:

1. Survei Tempat Pelaksanaan Kegiatan

Kegiatan ini dimaksudkan untuk menggali informasi tentang kondisi geografis dan kondisi masyarakat di daerah tempat kegiatan. Informasi tersebut berupa lokasi, permasalahan yang dihadapi dalam pada lokasi tersebut.

2. Persiapan Sarana dan Prasarana

Kegiatan ini dimaksudkan untuk merencanakan kebutuhan baik sarana dan prasarana yang akan digunakan dalam pelaksanaan kegiatan dengan tetap memperhatikan kebutuhan 
masyarakat secara umum dan khusus demi tercapainya target pengabdian kepada masyarakat. Sarana dan prasarana yang dimaksud berupa projektor, spanduk dan lain-lain.

3. Pelaksanaan Kegiatan

Setelah melakukan survey dan persiapan sarana dan prasarana maka pelaksanaan kegiatan dilaksanakan oleh pengusul beserta anggota dan beberapa mahasiswa. Kegiatanyang dilakukan adalah berupa pelatihan dalam bentuk pertemuan secara langsung antara guruguru pada SMPN 83 Jakarta yang membahas tentang pembuatan soal HOTS .

4. Monitoring dan Evaluasi

Kegiatan ini dimaksudkan untuk meninjau perkembangan aktualisasi masyarakat terhadap kegiatan yang telah dilakukan sebelumnya dengan harapan dapat dilaksanakan sesuai dengan teori yang telah diperoleh melalui kegiatan yang telah dilaksanakan. Evaluasi juga bertujuan untuk memahami pola pemahaman masyarakat terhadap informasi baru yang diperoleh dari pelaksana kegiatan. Hasil ini diharapkan mampu meningkatkan kapasitas guru-guru dalam pembuatan soal HOTS guna mendorong peserta didik untuk berpikir secara luas dan mendalam tentang materi pelajaran.

\section{HASIL DAN PEMBAHASAN}

Kegiatan penyuluhan dan pelatihan dilaksanakan pada tanggal 5, 6, dan 7 Desember 2019 di SMP Negeri 83 Jakarta yang beralamatkan di Jl. Empang Bahagia Raya Jelambar Kota Jakarta Barat kode pos 11460, Kelurahan/Desa Jelambar, Kecamatan Grogol Petamburan, Kota Jakarta Barat, D.K.I. Jakarta, tentang Pengembangan Kapasitas SDM dalam Dunia Pendidikan, penyuluan dan pelatihan ini dilakukan pada guru-guru SMP Negeri 83 Jakarta dengan jumlah sebanyak 21 peserta. Kegiatan penyuluhan dan Pelatihan ini dimulai dengan melakukan Ice Breaking tujuannya untuk membuat suasana lebih akrab. Setelah itu, pemateri menayangkan slide power point yang berkaitan dengan materi pembuatan soal HOTS. Respon dari para guru sangat baik. Terlihat ketika pemateri menanyakan pembuatan soal HOTS salah satu guru respon guru cepat menangkap pelajaran dari materi tersebut.

Dalam kegiatan tersebut ada beberapa perubahan yang dilihat dari guru - guru yang mengikuti kegiatan pelatihan dan pembinaan pengembangan kapasitas SDM dalam dunia pendidikan karena ada beberapa guru yang sangat bersemangat dan termotivasi untuk meningkatkan keterampilan dalam proses pembelajaran. Mereka menyadari selama ini mereka membuat instrumen soal dengan tingkatan keterampilan berpikir rendah sehingga pesera didik lebih menyukai belajar menghafal dan mengerjakan soal-soal yang ada pada buku dibandingkan mengembangkan kemampuannya pada level berpikir tingkat tinggi ketika hendak memecahkan masalah.

Alhamdulillah kegiatan pelatihan dan pembinaan pengembangan kapasitas SDM dalam dunia Pendidikan berjalan cukup baik, karena semua guru aktif dan merespon dengan baik dalam kegiatan ini. Berdasarkan wawancara, tanya jawab dan pengamatan langsung selama kegiatan berlangsung, kegiatan pengabdian pada masyarakat ini memberikan hasil sebagai berikut: Meningkatnya pengetahuan dan pemahaman para guru SMP Negeri 83 Jakarta tentang pembuatan soal HOTS. 


\section{KESIMPULAN DAN SARAN}

\section{Simpulan}

Pelaksanaan kegiatan Pengabdian Kepada Masyarakat oleh Lembaga Penelitian dan Pengabdian Masyarakat (LPPM) Universitas Pamulang yang dilakukan oleh dosen-dosen program studi Manajemen telah berjalan dengan lancar dan mendapat sambutan hangat dari tempat pelaksanaan kegiatan ini yaitu Kepala SMPN 83 Jakarta. Harapan kami dengan pengabdian ini dapat menambah ilmu yang bermanfaat dalam memberikan pemahaman kepada para guru agar dapat mengembangkan kapasitas mengajar dalam dunia pendidikan khususnya dalam pembuatan soal HOTS.

Dalam laporan kegiatan ini mungkin banyak kekurangan yang ada, untuk itu kami berharap masukan dan kritikan dalam rangka perbaikan untuk kegiatan-kegiatan pengabdian masyarakat di masa yang akan datang. Semoga kegiatan pengabdian masyarakat ini dapat bermanfaat bagi masyarakat sekitar lingkungan Universitas Pamulang dan lainnya. Kami mengucapkan terimakasih kepada seluruh pihak yang telah mendukung kegiatan yang kami laksanakan dan kami mohon maaf apabila dalam laporan ini banyak ditemukan kekurangan.

\section{Saran}

Berdasarkan hasil pengabdian masyarakat yang telah dilaksanakan, maka kami memberikan saran:

1. Kepada para guru agar mereka dapat meningkatkan ketrampilan dalam mengembangkan soal HOTS.

2. Kepada para guru agar memberikan penjelasan tentang ciri-ciri dan cara pengembangan soal HOTS yang berkualitas baik melalui praktik langsung yang dipresentasikan sehingga peserta didik mengetahui kekurangannya.

3. Kepada para guru agar menumbuhkan kesadaran diri yang tinggi tentang pentingnya mengembangkan kemampuan mengevaluasi peserta didik dengan selalu mengikuti perkembangan zaman dan teknologi.

\section{DAFTAR PUSTAKA}

Boediono. (2008). Pendidikan dan Latihan Dalam Periode Tinggal Landas. Mimbar Pendidikan, No. 1 Tahun XIII.

Budiman, A., \& Jailani, J. (2014). Pengembangan instrumen asesmen higher order thinking skill (HOTS) pada mata pelajaran matematika SMP kelas VIII semester 1. Jurnal Riset Pendidikan Matematika, 1(2), 139-151.

Fanani, M. Z. (2018). Strategi Pengembangan Soal Hots Pada Kurikulum 2013. Edudeena, 2(1).

Jones, J \& Walter, L. (2008). Human Resource Management in Education. Manajemen Sumberdaya Manusia dalam Pendidikan. Yogyakarta: Q-Media

Lewy, Z., \& Aisyah, N. (2009). Pengembangan Soal untuk Mengukur Kemampuan Berpikir Tingkat Tinggi Pokok Bahasan Barisan dan Deret Bilangan di Kelas IX Akselerasi SMP Xaverius Maria Palembang. Jurnal Pendidikan Matematika. Vol 3 No 2 (online). Tersedia di http://ejournal.unsri.ac.id. Diakses pada 06 September 2016 
Rofiah, E., dkk. (2013). Penyusunan Instrumen Tes Kemampuan Berpikir Tingkat Tinggi Fisika pada Siswa SMP. Jurnal Pendidikan Fisika, 1(2), hlm. 17-22.

Suryadi, A. (2006). Kebijaksanaan Pendidikan dan Pengembangan Sumberdaya Manusia:

Transisi Menuju era Indonesia Modern. Jakarta: Pusat Informatika, Balitbang Dikbud 